\title{
THE IMPACT OF SECURITY AND CUSTOMIZATION ON CONTINUANCE INTENTION OF M-BANKING
}

\author{
Mousa Albashrawi \\ King Fahd University of Petroleum and Minerals \\ Dhahran 31261, Saudi Arabia
}

\begin{abstract}
User satisfaction is crucial to reinforce continued usage intention of m-banking. Since banking industry considers satisfaction and loyalty as bottom-line goals, antecedents of such consequence need to be investigated. Prior research has focused more on m-banking behavioral intention rather m-banking continuance intention nevertheless the latter shows more strategic and economic value. Secondly, the role of customization and security, though its importance, has been overlooked in m-banking research. Technology acceptance model (TAM) with extended expectation-confirmation model in IT (ECM-IT) are employed to evaluate the factors influencing satisfaction, which in turn influences continuance intention of m-banking. Structural equation modeling (SEM) will be used to analyze the data and test the developed hypotheses. This research in progress has potential contributions to both academia and industry.
\end{abstract}

\section{KEYWORDS}

Customization, Security, M-banking, Continued Usage Intention, TAM, and ECM-IT

\section{INTRODUCTION}

The rapid pace of advancements in the world of technologies has imposed many challenges on organizations, especially those in FinTech industry. M-banking, a FinTech tool, enables customers to conduct financial transactions in a faster and easier fashion. This tool is defined as the use of mobile device (e.g. Smartphones) to perform many functions on the go, such as making payment, transferring fund, checking balance, etc. M-banking derives its popularity from the easy access to bank's services at anytime and anywhere. This type of convenience has been considered a big factor in increasing the adoption rate of m-banking. However, $\mathrm{m}$-banking comes with challenges that may burden banks and other financial institutions, for example, providing customized services, secure environment, higher promotion, etc.

M-banking adoption has been amply examined in IS research (Riquelme \& Rios, 2010; Lin, 2011; Oliveira et al. 2014). A few other studies have been developed to explore continued IT usage intention such as Hong et al. (2006) who used technology acceptance model (TAM), expectation-confirmation model (ECM-IT) and extended ECM-IT to examine the continuance intention of mobile internet. Yuan et al. (2014) and Mohammadi (2015) used TAM also for examining m-banking continuance intention. However, prior research has not paid much attention to the impact of customization and security in m-banking although their importance has been emphasized in online environment (Devaraj et al., 2006) and in banking sector (Coelho $\&$ Henseler, 2012). This has motivated us to explore this area through our research question: How customization and security influence continuance intention of m-banking. We believe that TAM would be appropriate to be used in our study because previous research has indicated that TAM is a good fit to study continued usage intention of experienced IT users (Hong et al., 2006).

This study can contribute to theory and practice. First, extending TAM with overlooked but important factors in the context of m-banking is our main contribution that can enrich theoretical knowledge in m-banking research. Second, this research can reveal the role of customization and security in m-banking and hence enable banks to take advantage of the study's insights by implementing a proper action. 


\section{RELATED WORK}

Many research studies have mainly focused on adoption and behavioral intention of m-banking, for example, Chung \& Kwon (2009) used TAM with its two factors of perceived usefulness and perceived ease of use, and proposed that technical support positively moderates the relationship between TAM's two pillars and adopting m-banking. Riquelme \& Rios (2010) also used TAM to explore m-banking adoption, but with gender as a moderating factor. Another study found that multidimensional trust and multi-faceted risk perceptions can influence behavioral intention to use m-banking (Luo et al., 2010). Lin (2011) studied how attitude and behavioral intention to use m-banking can be impacted by knowledge-based trust and innovation attributes. Recently, Oliveira et al. (2014) integrated three models; technology-task fit (TTF), unified theory of acceptance and use of technology (UTAUT), and initial trust model (ITM) to provide a holistic framework that determine m-banking adoption among Portuguese university students. Hanafizadeh et al. (2014) also used the student sample and expanded TAM with trust, credibility, and compatibility with life style to investigate their effects of on m-banking behavioral intention. As well, Pavithran et al. (2014) utilized TAM to examine m-banking adoption in the context of a developing country.

M-banking continuance intention has been underlined in IS literature to be more important than behavioral intention because it can provide a good indication to customer's loyalty (Hew et al., 2016). A few studies, though, have paid attention to continuance intention of m-banking; for instance, Zhou \& Liu (2014) combined ECM-IT and flow theory to investigate continuance intention of m-banking users in China. Likewise, Yuan et al. (2014), Mohammadi (2015), Albashrawi \& Motiwalla (2017) examined continuance intention of m-banking users in China, Iran, and USA, respectively through extending TAM with different factors such as risk, awareness, resistance, privacy, gender, subjective norms, and personal innovativeness. Despite its economical value, m-banking continuance intention has scant studies in IS literature and hence further research in this area is needed to increase the understanding and advance theoretical knowledge.

Security and customization are two embedded factors in most information systems and have been plentifully highlighted in prior research to understand satisfaction and continued usage intention of IT users (Coelho \& Henseler, 2012; Guo et al., 2012; Ozer et al., 2013), but not explored yet in m-banking context especially as interaction effects. From an industry perspective, 70\% of banks have shown their concerns regarding security as the biggest barrier to move forward with m-banking (Crowe et al., 2015). While customizing user experience with adding special tools in $\mathrm{m}$-banking may increase satisfaction and generate more revenue (Townsend, 2014). Since academic research and industry reports have emphasized the importance role of security and customization, we integrate them to our theoretical model.

\section{HYPOTHESES AND RESEARCH MODEL}

TAM has two pillars; perceived usefulness in which described as an assessment of how IT can improve job performance and perceived ease of use in which described as an assessment of how IT can be effortless (Davis, 1989). Bhattacherjee (2001) determined that perceived usefulness has a positive influence on satisfaction. Likewise, Joo et al. (2011) concluded that both TAM pillars are significant predictors of satisfaction in online university environment. Accordingly, we hypothesize that:

\section{H1: Perceived ease of use is positively related to customer satisfaction of m-banking.}

H2: Perceived usefulness is positively related to customer satisfaction of m-banking.

Customization in m-banking describes the adjustments made to m-banking services based on customer needs and wants. Once m-banking provides customized services according to the users' preferences, the users may show a higher satisfaction towards it. Prior research showed a theoretical support of this relationship (Coelho \& Henseler, 2012). In addition, Devaraj et al. (2006) found that when online store provides personalized and customized services, the customers tend to be satisfied. Besides IS literature, we think that once m-banking enables customization, the users may perceive the services to exhibit a higher level of friendly use and provides more productivity, which in turn leads to a higher level of satisfaction. 
On the other hand, security describes to what extent m-banking users feel safe and not vulnerable to online attacks. Shen et al. (2010) emphasized that m-banking provides convenience as a main advantage, but is attached with security as a main disadvantage. Guo et al. (2012) suggested that a higher level of security can generate a higher customer satisfaction in online shopping environment. It can be argued that when security is reinforced in m-banking, its embedded services could be seen to be more usable and useful, leading to a higher level of satisfaction among the users. From a practical side, banks are most likely to be interested to understand the role of customization and security in having more satisfied users of m-banking. According to the above, customization and security as moderating variables are worthy to investigate and thus hypothesized below as:

H3: The higher level of customization, the greater positive relationship between perceived ease of use and customer satisfaction of m-banking.

H4: The higher level of customization, the greater positive relationship between perceived usefulness and customer satisfaction of m-banking.

H5: The higher level of security, the greater positive relationship between perceived ease of use and customer satisfaction of m-banking.

H6: The higher level of security, the greater positive relationship between perceived usefulness and customer satisfaction of m-banking.

Bailey \& Pearson (1983) defined customer satisfaction as: "satisfaction in a given situation is the sum of one's feelings or attitudes toward a variety of factors affecting that situation". Bhattacherjee (2001) used ECM-IT model and proposed that continued IT usage intention is predicted by user satisfaction. In the same vein, Hong et al. (2006) extended ECM-IT and suggested that IT usage intention is determined by customer satisfaction. In essence, when a customer is satisfied with IT product or service, he/she will be more willing to continue using it. Since $\mathrm{m}$-banking is no exception, the above can lead us to hypothesize that:

H7: Customer satisfaction is positively related to continued usage intention of m-banking.

As per the hypothesized relationships, a research model is developed from TAM and depicted in Figure 1. The model shows TAM's two pillars are independent variables; customization and security are moderating variables; customer satisfaction and continued m-banking usage intention are dependent variables.

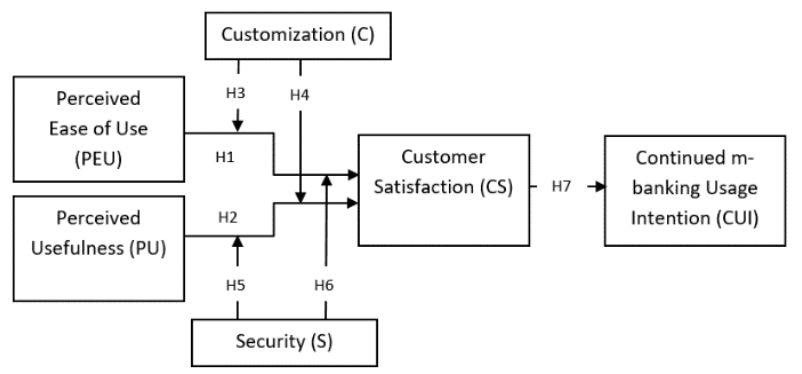

Figure 1. Research Model

\section{RESEARCH METHOD}

Our sample will be collected from a mid-sized US bank's customers who use m-banking. We will use SurveyMonkey to invite m-banking users to complete the questionnaire online. A 7-point, Likert-type scale is implemented to measure the survey items with a range of 1, "strongly disagree" to 7, "strongly agree". Structural equation modeling (SEM) will be employed to test the hypothesized relationships in the research model. We will control for other variables that could influence m-banking continuance intention, for example, age, gender, and education. 
Study's constructs were adapted from literature in a similar area and modified to m-banking context as shown in Table 1 below. Perceived usefulness and perceived ease of use were adapted from Davis (1989). Customization was adapted from Suki (2011) and Coelho \& Henseler (2012) whereas security was adapted from Shen et al. (2010). Customer satisfaction was adapted from Fornell et al. (1996) and Thong \& Tam (2006). Continued m-banking usage intention was adapted from Hong et al. (2006).

Table 1. Constructs Operationalization

\begin{tabular}{|c|c|c|}
\hline Construct & $\begin{array}{l}\text { Item } \\
\text { Code }\end{array}$ & Lead Questions \\
\hline Perceived & PU1 & Q1. Overall, I find mobile banking to be useful. \\
\hline \multirow[t]{3}{*}{ Usefulness } & PU2 & Q2. Using mobile banking enables me to process financial transactions quickly. \\
\hline & PU3 & Q3. Using mobile banking improves my performance in conducting financial transactions. \\
\hline & PU4 & Q4. Using mobile banking enhances my productivity with financial transactions. \\
\hline \multirow{5}{*}{$\begin{array}{l}\text { Perceived Ease } \\
\text { of Use }\end{array}$} & PEU1 & Q5. Overall, I find mobile banking to be easy to use. \\
\hline & PEU2 & Q6. Mobile banking is easy for doing what I want to do. \\
\hline & PEU3 & Q7. My interactions with mobile banking are clear and understandable. \\
\hline & PEU4 & $\begin{array}{l}\text { Q8. I find that mobile banking is flexible to interact with } \mathrm{t} \text { is easy to become skillful at using } \\
\text { mobile banking. }\end{array}$ \\
\hline & PEU5 & Q9. It is easy to become skillful at using mobile banking. \\
\hline \multirow[t]{8}{*}{ Security } & S1 & Q10. Overall, I find mobile banking to be secure. \\
\hline & $\mathrm{S} 2$ & Q11. I am suspicious of security techniques used in mobile banking. \\
\hline & S3 & $\begin{array}{l}\text { Q12. I am concerned that other people may steal my account information when using mobile } \\
\text { banking. }\end{array}$ \\
\hline & S4 & Q13. I am confident that mobile banking provides adequate security. \\
\hline & S5 & $\begin{array}{l}\text { Q14. I think that there is a higher security risk associated with mobile banking compared to } \\
\text { branch banking. }\end{array}$ \\
\hline & S6 & $\begin{array}{l}\text { Q15. I think that there is a higher security risk associated with mobile banking compared to } \\
\text { internet (online) banking. }\end{array}$ \\
\hline & S7 & Q16. I feel that mobile banking is a safe environment for conducting my financial transactions \\
\hline & S8 & $\begin{array}{l}\text { Q17. I think that mobile banking will be more secure if it sends all transactions confirmations to } \\
\text { my personal email. }\end{array}$ \\
\hline \multirow[t]{5}{*}{ Customization } & $\mathrm{C} 1$ & Q18. Overall, I find mobile banking is customized to my personal needs. \\
\hline & $\mathrm{C} 2$ & Q19. I feel that mobile banking offers me services that satisfy my specific needs. \\
\hline & $\mathrm{C} 3$ & Q20. I find that mobile banking provides me with services according to my preference. \\
\hline & $\mathrm{C} 4$ & Q21. Mobile banking with Enterprise Bank offers services that I could NOT find in other banks. \\
\hline & $\mathrm{C} 5$ & Q22. If I changed to another bank, I would NOT obtain services as customized as I have now. \\
\hline Customer & CS1 & Q23. Overall, I am satisfied with my mobile banking experience. \\
\hline Satisfaction & $\mathrm{CS} 2$ & Q24. Mobile banking experience meets my expectations. \\
\hline \multirow{3}{*}{$\begin{array}{l}\text { Continued M- } \\
\text { Banking Usage } \\
\text { Intention }\end{array}$} & CUI1 & Q25. I intend to continue using mobile banking services in the future. \\
\hline & CUI2 & Q26. I intend to increase my time spent using mobile banking in the future. \\
\hline & $\mathrm{CU13}$ & 7. I intend to increase my use of various services provided by mobile banking in the future \\
\hline
\end{tabular}

\section{CONCLUSION}

This research in progress explores the interaction effect of customization and security on continuance intention of m-banking. It is important to divert the research focus from behavioral intention to continuance intention because the latter has been scarcely studied in m-banking. Secondly, m-banking continuance intention has a greater value to practice due to its direct impact on customer loyalty. However, this study is limited with the use of survey, which is a self-reported tool that may generate bias. Thus, future studies in m-banking should seek to employ a longitudinal design to better reflect causality among the relationships. 


\section{REFERENCES}

Albashrawi, M. \& Motiwalla L., 2017. Privacy and Personalization in Continued Usage Intention of Mobile Banking: An Integrative Perspective. Information Systems Frontires, pp. 1-13.

Bailey, J.E. \& Pearson, S.W., 1983. Development of a Tool for Measuring and Analyzing Computer User Satisfaction. Management Science, Vol. 29, No. 5, pp. 530-545.

Bhattacherjee, A., 2001. Understanding Information Systems Continuance: An Expectation Confirmation Model. MIS Quarterly, Vol. 25, No. 3, pp. 351-370.

Chung, N. \& Kwon, S.J., 2009. The Effects of Customers' Mobile Experience and Technical Support on the Intention to Use Mobile Banking. Cyberpsychology \& Behavior, Vol. 12, No. 5, pp. 539-543.

Coelho, P.S. \& Henseler, J., 2012. Creating Customer Loyalty through Service Customization. European Journal of Marketing, Vol. 46, No. 3/4, pp. 331-356.

Crowe, M., Tavilla, E. \& McGuire, B., 2015. Mobile Banking and Mobile Payment Practices of US Financial Institutions: Results from 2014 Survey of FIs in Five Federal Reserve Districts, Federal Reserve Boston, pp. 1-66.

Davis, F.D., 1989. Perceived Usefulness, Perceived Ease of Use, and User Acceptance of Information Technology. MIS Quarterly, Vol. 13, No. 3, pp. 319-340.

Davis, F.D. et al, 1989. User Acceptance of Computer Technology: A Comparison of Two Theoretical Models. Management Science, Vol. 35, No. 8, pp. 982-1003.

Devaraj, S. et al, 2006. Examination of Online Channel Preference: Using the Structure-Conduct-Outcome Framework. Decision Support Systems, Vol. 42, No. 2, pp. 1089-1103.

Fornell, C. et al, 1996. The American Customer Satisfaction Index: Nature, Purpose, and Findings. Journal of Marketing, Vol. 60, pp.7-18.

Guo, X. et al, 2012. Evaluating Factors Influencing Consumer Satisfaction towards Online Shopping in China. Asian Social Science, Vol. 8, No. 13, pp. 40-50.

Hanafizadeh, P. et al, 2014. Mobile-Banking Adoption by Iranian Bank Clients. Telematics and Informatics, Vol. 31, No. 1, pp. 62-78.

Hew, J.J., et al, 2016. Mobile Social Commerce: The Booster for Brand Loyalty?. Computers in Human Behavior, Vol. 59, pp 142-154.

Hong, S.-J. et al, 2006. Understanding Continued Information Technology Usage Behavior: A Comparison of Three Models in the Context of Mobile Internet. Decision Support Systems, Vol. 42, pp. 1819-1834.

Joo, Y.J. et al, 2011. Online University Students' Satisfaction and Persistence: Examining Perceived Level of Presence, Usefulness and Ease of Use as Predictors in a Structural Model. Computers \& Education, Vol. 57, No. 2, pp. 1654-1664.

Lin, H.F., 2011. An Empirical Investigation of Mobile Banking Adoption: The Effect of Innovation Attributes and Knowledge-Based Trust. International Journal of Information Management, Vol. 31, pp. 252-260.

Luo, X., et al, 2010. Examining Multi-Dimensional Trust and Multi-Faceted Risk in Initial Acceptance of Emerging Technologies: An Empirical Study of Mobile Banking Services. Decision Support Systems, Vol. 49, pp. 222-234.

Mohammadi, H., 2015. A Study of Mobile Banking Loyalty in Iran. Computers in Human Behavior, Vol. 44, pp. 4435-47.

Oliveira, T. et al, 2014. Extending the Understanding of Mobile Banking Adoption: When UTAUT meets TTF and ITM. International Journal of Information Management, Vol. 34, No. 5, pp. 689-703

Ozer, A., et al, 2013. The Effect of Mobile Service Quality Dimensions on Customer Satisfaction. Procedia-Social and Behavioral Sciences, Vol. 99, pp. 428-438.

Pavithran, R., et al. 2014. An Empirical Investigation of Mobile Banking Adoption in Developing Countries. International Journal of Enterprise Information Systems, Vol. 10, No. 1, pp. 76-93.

Riquelme, H.E. \& Rios, R.E., 2010. The Moderating Effect of Gender in the Adoption of Mobile Banking. International Journal of Bank Marketing, Vol. 28, pp. 328-341.

Shen, Y.C., et al, 2010. A Benefit-Cost Perspective of the Consumer Adoption of the Mobile Banking System. Behaviour \& Information Technology, Vol. 29, No. 5, pp. 497-511.

Suki, N.M., 2011. A Structural Model of Customer Satisfaction and Trust in Vendors Involved in Mobile Commerce. Int. Journal of Business Science and Applied Management, Vol. 6, No. 2, pp. 17-30.

Townsend, Z., 2014. Era of Mass Customization in Banking. Bank Innovation, retrieved from: https://bankinnovation.net/2014/04/era-of-mass-customization-in-banking/

Yuan, S., et al, 2014. An Investigation of Users' Continuance Intention towards Mobile Banking in China. Information Development, Vol. 32, No. 1, pp. 20-34.

Zhou, T. \& Liu, Y., 2014. Examining Continuance Usage of Mobile Banking from the Perspectives of ECT and Flow. International Journal of Services Technology and Management, Vol.20, No. 4-6, pp. 199-214. 